\title{
The Effects of Environmental Munificence and Market Orientation Dimensions on Performance of Small Business Firms in Botswana
}

\author{
Olumide Olasimbo Jaiyeoba (Corresponding author) \\ Department of Marketing, Faculty of Business \\ University of Botswana, Gaborone
}

Received: July 13, 2013 Accepted: August 2, 2013

doi:10. 5296/ber.v3i2.4687 URL: http://dx.doi.org/10. 5296/ber.v3i2.4687

\begin{abstract}
The significance and importance of the relationship between market orientation and environmental munificence is clearly embedded in the extant literature. There is however the acute paucity or conceptual ambiguity of such investigation in developing economies.Thus, this study aims to investigate the effects of environmental munificence and market orientation dimensions on performance of small business firms in Botswana. While there is a rich body of research on market orientation抯 effect on business performance, much little attention has been given to the combined effects of environmental munificence and market orientation on small businesses in developing economies. To provide insights into the above inconsistencies, this study hope to generate empirical results on the combined effects of market orientation and environmental munificence on small business performance in Botswana
\end{abstract}

Keywords: Environmental Munificence, Market Orientation, Small Business Firms, Botswana.

\section{Introduction}

Botswana has long realized the importance of Small firms in fostering economic growth and in creating jobs. This led to the introduction, over the last two decades, of targeted financial support as well as advisory programmes to help Batswana establish their own enterprises. These programmes, however, were set up more in reaction to specific problems encountered rather than as the basis of a comprehensive and more focused government policy on Small businesses. Over the last decade, considerable changes have taken place in the world economic order, brought about by a number of factors. The most important new factor is the growing intensity of international competition, spurred by the advent of globalization. The other factor 
that is increasing competitiveness is the rapid introduction of more productive technology and improved operating procedures in business enterprises throughout the world. The significance and importance of the relationship between market orientation and environmental munificence is clearly embedded in the existent literature. There is however the acute paucity or conceptual ambiguity of such investigation in developing economies.Thus, this study aims to investigate the effects of environmental munificence and market orientation dimensions on performance of small business firms in Botswana. The research community largely shares the view that growing Small firms have a special importance in the economy (Storey,1994). Although there has been much interest in understanding small firm growth during the last twenty years (Dobbs and Hamilton,2007;O扲egan et al.,2006;Wiklund,1998;Delmar et al,2003), there is still not much of a common body or nexus of relationship of well founded knowledge about the causes, effects or processes of growth (Davidsson and Wiklund,2000). While there is a rich body of research on market orientation抯 effect on business performance, much little attention has been given to the combined effects of environmental munificence and market orientation on small businesses in developing economies. Also a rich body of research in marketing has examined the relationship between market orientation-firms?focus on the identification and satisfaction of customer needs and business performance (Ellis 2006;Kirca et al,2005).Still, our understanding of the relationship between market orientation and environmental munificence, which is also central for firms?growth and competitive advantage, is much more limited, most especially in Africa. To provide insights into the above inconsistencies, this study hope to generate empirical results on the combined effects of market orientation and environmental munificence on small business performance in Botswana. Environmental munificence is the scarcity or abundance of critical resources needed by firms operating within an environment (Randolph\& Dess,1984).The resources available within an environment influence the survival and growth of firms sharing that environment, they also affect the abilities of new firms to enter this environment (Randolph\& Dess,1984).Research has indicated that environmental munificence is positively associated with the range of strategy and organization options available to firms, including market orientation dynamics.(Tushman \&Anderson,1986). When resources are abundant, it is relatively easy for firms to survive, and pursue goals other than survival.However,when resources are scarce, competition intensifies (Dess \& Beard,1984),adversely affecting firm profitability and organizational slack and causing changes in interorganisational characteristics and tangible and intangible behaviors of organizational members . Together, these findings suggest that munificence is an important theoretical dimension.

\section{Literature Review}

The environment creates opportunities and threats for an organization. It affects organizational structure, processes, and managerial decision making (Duncan,1972;Keats and Hitt,1988). The environment creates uncertainty for an organization抯 managers which in turn influences the information processing needs within the top management team most especially in small business firms in developing economies. Zahra et al., (1999) thus call for comparative entrepreneurship studies across multiple countries and cultures, with the underlying premise that different cultural and economic contexts may lead to differential intensities of 
entrepreneurial orientation and its antecedents and consequences. Managers must cope with uncertainty by identifying opportunities, recognizing problems or threats, and by implementing strategic adaptations (Hambrick,1980;Jemison,1984). Therefore, the study of different regions, cultures, economies and environments becomes a research priority if we want a full understanding of the nature and the role of entrepreneurship and market orientation. Environmental munificence refers to environmental capacity which permits organizational growth and stability. Munificence can also facilitate the generation of slack resources (Cyert and March, 1963) which the organization can use during periods of scarcity or which can be used for organizational innovation. Hostile market environments characterized by intense competition and lack of exploitable opportunities, and dynamic market environments characterized by rapid technological advancements and rapidly changing consumer preferences, are considered to have a significant influence on business performance (Covin and Slevin,1989;Gray et al.,1998;Jaworski and Kholi,1993;Low,2000;Kumar and Srivastava,2004; Slater and Narver,1994).Clearly, the desire to be competitive in such environmental conditions may provide the impetus for organizations to implement marketing audits to ensure the marketing executives to have adequate environmental information for market conduct, most especially amongst small business firms in developing economies. In the literature, environment has been defined as a multidimensional concepts (Egeren and onnor, 1998).Following Egeren and onnor (1998) approach, this study will define environment in terms of marketing manager perceptions of munificence and dynamic attributes.

\section{Conceptual Models and Hypotheses Development}

Group cohesiveness has been shown to be related to the quantity of interaction (Lott and Lott, 1961) and quality of interaction (Shaw, 1964) between group members, most especially amongst small business firms. Connectedness between departments facilitates interaction and the exchange of information (Ruekert \& Walker, 1987). Kirca et al.,(2005), analogously concluded that managers can improve market orientation by emphasizing market-oriented attitudes, behaviors, and reward systems; tolerating acceptable risk; communicating effectively; embracing change; and providing opportunities for staff development or advancement while avoiding formalization, centralization, and interdepartmental conflict. The perception of an organization as being comprised of different but interdependent departments and functions, together with the availability of conflict resolution mechanisms, facilitates the open flow of resources, work and assistance across all organizational departments (Ruekert \& Walker 1987).Based on this reasoning, Jaworski and Kholi (1993) postulate that interdepartmental connectedness fosters an interdependency within the organization and encourages employees to act in a concerted manner in the processes of knowledge generation and knowledge utilization. Thus, the following hypothesized relationship could be established:

H1: The higher the level of top management cohesiveness, the higher the Small Business Firm担 level of market orientation.

Communication affects strategic decision making by influencing the breadth of the field of vision during the intelligence generation and dissemination activities of market orientation, and the processing of information during the intelligence response activities. Kholi and 
Jaworski,(1993), therefore concluded that the role of senior management is critical in shaping organizational values to promote and reinforce behaviors necessary to serve the current and future needs of customers, better than their key competitors. Burgess and Nyajeka,(2007),posited that besides top management reinforcement, their commitment of continuous communication of specific guidelines to be market-oriented was considered mandatory to encourage organizational employees, in order to create, disseminate and effectively respond to market intelligence. Two types of intergroup conflict affect organizations: relationship conflict and task conflict (Polzer, Milton, \& Swann,2002).Burgess and Nyajeka, (2007), thus postulate that relationship conflict emerges from interpersonal incompatibility, produces frustration, annoyance and tension; thus reducing information sharing and causes employees to disengage psychologically and physically from a firm. Atuahene-Gima \& Murray,(2004),concluded that high task conflict adversely affect marketing strategy development by stifling cross-functional cooperation. The following hypothesized relationship could be established:

$\mathrm{H} 2$ : The higher the level of communication exhibited by top management, the higher the organization level of market orientation.

The literature in business policy and strategic management has long stressed the need to scan and assess the organization担 environment and to align environmental characteristics with organizational capabilities and goals (Miles and Snow,1978). Khandwalla (1976), found that when managers perceived their environments as being dynamic and uncertain, their strategies were more likely to be extenstive, more comprehensive and more multifaceted. Environmental munificence means a great availability of resources in the environment and great opportunity in access and acquirement of resources needed. This is in line with the position of Covin and Slevin (1991); and Brown and Kirchhoff,(1997).Environmental munificence, thus refers to environmental capacity which permits organizational growth and stability. Kholi and Jaworski, (1990), thus concluded that in those environments high in munificence, an organization may be able to get away with a minimal amount of market orientation. Dess and Beard, 1984, postulate that in environments low in munificence, competition increases. In some cases, the intensity of the relationship between entrepreneurship and market orientation depends on the context in which firms operate. Covin and Slevin, (1989), posited that the relationship between entrepreneurship and performance is higher when environmental hostility increases. Dess et al., (1997), also argue that entrepreneurial orientation may be especially useful in uncertain or turbulent environments. Knight (2000), concluded that entrepreneurship may be useful for small business firms affected by globalization. This reasoning suggests that organizations will respond to low munificence by using a higher degree of market orientation. The following hypothesized relationship is posited in this study:

H3: Small Business Firms in environments low in munificence will exhibit a higher degree of market orientation than Small Business Firms in environments high in munificence.

Market instability or dynamism can come from changes in consumers and in consumers preferences. In environments marked by stable preferences, there is little need for an organization to adjust its marketing mix. In contrast, in an environment marked by rapidly 
changing sets of consumers and consumers taste and preferences, there is greater likelihood that the organization担 offerings will be mismatched with consumer needs. Technological turbulence, competitive intensity, and the state of the economy can also bring about environmental dynamism, which could create diverse opportunities leading to creating value for consumers, thus making strong market orientation more desirable. Dynamism is the degree of change or market or market stability.Overall,the reason why market environment characteristics may influence marketing audits is because marketing audits provide the marketing management with programmed appraisals and critical evaluations of the environmental analysis and help ensure the marketing management to identify opportunities and threats from markets. Dynamic environment is likely to generate opportunities, which the growth-oriented businesses can take advantage of (Covin \& Slevin,1991;Zahra,1993).In their study of independent Swedish small businesses, Wiklund and Shepherd,(2003), found that environmental dynamism magnifies the effect the managers rowth aspirations have on the realization of growth. Based on the discussion earlier, the following exploratory propositions are presented:

H4: Small Business Firms in environments high in dynamism will exhibit a higher degree of market orientation than Small Business Firms in environments low in dynamism.

Several empirical studies have found a strong positive relationship between Market orientation and performance, whether one looks at consumer products, new products, innovation or services. There is however, a small body of evidence that does not support a strong positive relationship between $\mathrm{MO}$ and business performance. A market orientation provides a unifying framework and focus for people and departments, thereby creating superior value for consumers and superior performance for organizations. In a meta-analysis of more than 200 effect sizes, Kirca et al., (2005) find that the effects of market orientation on performance are strongly positive, although somewhat weaker in emerging markets and service industries. The meta analysis of Cano et al., (2004) found that the effects of market orientation on performance are not moderated by national culture, GDP per capita, or human development and are stronger in service firms than in manufacturing firms. However, only three of the 53 studies they examined were located in developing economies and they theorized that developing economies cultural priorities would increase the positive impact of market orientation on performance. This is consistent with a priori findings of Deshpande and Farley (2004), which states that the effects of market orientation on performance should be highest in developing economies. Based on the discussion earlier, the following exploratory propositions are presented:

H5: Small Business Firms with a high degree of market orientation will have higher performance than Small Business Firms with a low degree of market orientation in Botswana.

Figure 1. Proposed model of Environmental munificence and market orientation dimensions effect on Small Business Firms In Botswana.

\section{Research Methodology}

The research design to be adopted in this study is cross-sectional. The target population in this study would be made up of top management teams of Small business firms in service and 
manufacturing firms as key informants for the firms. The CEOs of 150 small business firms would be interviewed. Group cohesiveness and communication amongst the small business firms would be measured by using a series of items to which key informants would respond using a five point Likert scale. This research intends to use a modification of Slater and Narver (1992) and Khandwalla (1976) measures to measure munificence, dynamism and organizational performance. Snowball sampling technique will be utilized due to lack of access to adequate sampling frame. LISREL (statistical technique of linear structural relations), would be utilized because it has the potential to address structural relationships among theoretical (latent) constructs that cannot be directly observed and its ability to incorporate measurement error in the model. All the scales used would be tested for unidimensionality and reliability in order to investigate the psychometric competence of scale items.

\section{Conclusions}

As to environmental ramifications for services marketing management, this study adds support to the intuitive claims of academicians, that environments high in dynamism and low in munificence engender higher degrees of market orientation. It could thus be concluded that those organizations which are in tune with their environments and recognize themselves as being in high dynamic or low munificence environments will be well advised to invest in becoming more market oriented.

This study will hopefully contribute to empirical evidence about the relationship among entrepreneurship, market orientation and performance. Because the adoption of entrepreneurship and market orientation as part of a firms organizational culture requires greater effort, it is crucial to understand the relationship of these orientations in terms of their implementations and implications for performance of small sized firms in Botswana. Therefore, policies aimed at enhancing entrepreneurial orientation and exploiting its complementarities with MO constitute an appropriate way to promote economic growth and welfare of small sized firms in Botswana.

\section{References}

Atuahene-Gima, K, \& Murray, J. Y. (2004). Antecedents and outcomes of marketing strategy competitiveness. Journal of Marketing, 68(4), 33-46. http://dx.doi.org/10.1509/jmkg.68.4.33.42732

Brown, T. E., \& Kirchhoff B. A. (1997). The Effects of Resource Availability and Entrepreneurial orientation on firm Growth. Frontiers of Entrepreneurship Research. Babson College.

Burgress, S. M \& Nyajeka, (2007). Market orientation and performance in low-income countries: The case of Zimbabwean retailers. Advances in International Management, 20, 215-257. http://dx.doi.org/10.1016/S1571-5027(07)20010-5

Covin., J. G., \& Slevin., D. P. (1989),Strategic Management of Small Firms in Hostile and Beningn Environments. Strategic Management Journal, 10(1), 75-87. http://dx.doi.org/10.1002/smj.4250100107 


\section{MInstitute ${ }^{\text {Mnk }}$}

Business and Economic Research ISSN 2162-4860

Cyert, R. M., \& March, J. G. (1963). A behavioural Theory of the Firm,Prentice-Hall, Englewood Cliffs, NJ.

Delmar., Davison., \& Gartner, W. B. (2003). Arriving at the high growth firm. Journal of Business Venturing, 18(2), 189-216. http://dx.doi.org/10.1016/S0883-9026(02)00080-0

Deshpande R., Farley, J. U, \& Webster, J. F. E (1993). Corporate culture, customer orientation and innovativeness in Japanese Firms: a quadrad analysis, Journal of Marketing, 57(1), 23-27. http://dx.doi.org/10.2307/1252055

Dess, G. C., \& Beard, D. W. (1984). Dimensions of organizational task environments. Administrative Science Quarterly, (29), 52-73. http://dx.doi.org/10.2307/2393080

Dobbs, M., \& Hamilton, R, (2007). Small business growth: recent evidence and new directions. International Journal of Entrepreneurial behaviour and Research, 13(5), 296-322. http://dx.doi.org/10.1108/13552550710780885

Duncan, R. B. (1972). Characeristics of organizational environments and perceived environmental uncertainty, Administrative Science Quarterly, 20, 613-629.

Egeren, M. V., \& O onnor, S. (1998). Drivers of Market orientation and performance in service $\begin{array}{lllll}\text { firms? } & \text { Journal of } & \text { Services } & \text { Marketing, } & \text { 12(1), }\end{array}$ http://dx.doi.org/10.1108/08876049810202357

Ellis, P. D, (2006). Market Orientation and performance : A meta analysis and cross national comparisons. Journal of Management Studies, 43(5), 1089-1107. http://dx.doi.org/10.1111/j.1467-6486.2006.00630.x

Gray, B. J., Matear, S., Boshoff, C., \& Matheson, P. K. (1998). Developing a Better Measure of Market Orientation. European Journal of Marketing. 32(9/10), 884-903. http://dx.doi.org/10.1108/03090569810232327

Hambrick, D. C., \& Mason, P. A. (1984). Upper echelons :the organization as a reflection of its top managers. Academy of Management Review, 9(2), 193-206.

Jemison, D. (1984). The importance of boundary spanning roles in strategic decision making. $\begin{array}{llll}\text { Journal of } & \text { Management } & \text { 131-152. }\end{array}$ http://dx.doi.org/10.1111/j.1467-6486.1984.tb00228.x

Keats, B. W., \& Hitt, M. A. (1988), A causal model of linkages among environmental dimensions macro organizational characteristics and performance. Academy of Management Journal, 31, 57-98. http://dx.doi.org/10.1111/j.1467-6486.1984.tb00228.x

Khandwalla, P. (1976). The Design of Organisations, Harcourt, Brace, Jovanovich, New York, NY.

Kholi, A. K., Jaworski, B. J., \& Kumar, A. (1993) MARKOR:A measure of MO, Journal of Marketing Research, 30 (Nov), 467-477. http://dx.doi.org/10.2307/3172691

Kirca, A. H, Jayachandran, S, \& Bearden, W. O (2005). Market Orientation: A meta-analytic 
review and assessment of its antecedents and impact on performance. Journal of Marketing. 69(2), 24-41. http://dx.doi.org/10.1509/jmkg.69.2.24.60761

Knight, G. (2000). Entrepreneurship and marketing strategy: the SME under globalization. Journal of International Marketing, 8(2), 12-32. http://dx.doi.org/10.1509/jimk.8.2.12.19620

Kumar, V., \& Srivastava, R. K. (2004). Measuring Marketing Productivity: Current Knowledge and Future Directions. Journal of Marketing, 68 (October), 76-89.

Lott and Lott (1961). Group cohesiveness, communication level and conformity, Journal of Abnormal and Social Psychology, 62, 408-412. http://dx.doi.org/10.1509/jimk.8.2.12.19620

Low, G. S. (2000) Correlates of Integrated Marketing Communications. Journal of Advertising Research, 40(3), 27-39.

Oegan , N., \& Ghobadian, A. (2006). Perceptions of generic strategies of small and medium sized engineering and electronics manufacturers in the UK: the applicability of the miles and Snow typology, Journal of Manufacturing Technology Management, 5(17), 603-620. http://dx.doi.org/10.1016/j.technovation.2005.01.003

Polzer, J. T., Milton, L. P., \& Swann., W. B. (2002). Capitalizing on diversity: Interpersonal congruence in small work groups. Administrative Science Quarterly, 47(2). 296-324. http://dx.doi.org/10.2307/3094807

Randolph. \& Dess (1984).The congruence perspective of organization design: a conceptual model and multivariate research approach, Academy of Management Review, 9(1), 114-127.

Rodriguez, Cano, C, Carrilat, F. A, \& Jaramillo, F, (2004). A meta-analysis of the relationship between Market orientation and Business Performance: Evidence from five continents. International Journal of Research in Marketing, 21(2), 179-200. http://dx.doi.org/10.1016/j.ijresmar.2003.07.001

Ruekert, R, \& Walker, O. C Jr. (1987). Marketing抯 interaction with other functional units:A conceptual framework and empirical evidence. Journal of Marketing. 51(1), 1-19.

Shaw, M. E. (1964). Group effectiveness as a function of group members compatibility and cooperation requirements of the task. Group Dynamics, 3rd edition, McGraw-Hill, New York, NY.

Slater, S. F. \& Narver, J. C. (1994) Does Competitive Environment Moderate the MO-Performance Relationship? Journal of Marketing. 58, 46-55. http://dx.doi.org/10.2307/1252250

Tushman, M. L., \& Anderson, P. (1986). Technological discontinuities and organizational environments. Administrative Science Quarterly. 31, 439-465. http://dx.doi.org/10.2307/1252250

Wiklund, J. (1998). Entrepreneurial orientation as predictor of performance and entrepreneurial behaviour in small firms:Longitudinal evidence In Frontiers of Entrepreneurial Research. Wellesey, MA:Babson College. http:www. babson. edu/entrep/papers. htm. 


\section{Macrothink}

Business and Economic Research ISSN 2162-4860 2013, Vol. 3, No. 2

Zahra, S. A., \& Covin, J. G. (1995). Contextual influences on the corporate entrepreneurial-performance relationship: A longitudinal analysis. Journal of Business Venturing, 10, 43-58. http://dx.doi.org/10.1016/0883-9026(94)00004-E

\section{Copyright Disclaimer}

Copyright reserved by the author(s).

This article is an open-access article distributed under the terms and conditions of the Creative Commons Attribution license (http://creativecommons.org/licenses/by/3.0/). 